Article

\title{
Destructive Effect of Water Vapour on an In Situ Diffusion Barrier Layer within an Aluminide Coating on IN738 Alloy
}

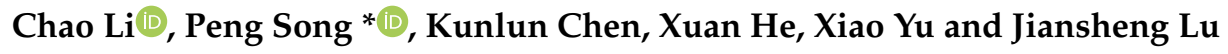 \\ Faculty of Materials Science and Engineering, Kunming University of Science and Technology, Kunming 650093, \\ China; chaolikmust@163.com (C.L.); kunlun0418@outlook.com (K.C.); zxcvbhx@outlook.com (X.H.); \\ 18468265115@163.com (X.Y.); jianslu@hotmail.com (J.L.) \\ * Correspondence: songpeng@kmust.edu.cn
}

Received: 19 August 2018; Accepted: 19 September 2018; Published: 21 September 2018

\begin{abstract}
High-temperature interdiffusion within a hot-dipped aluminide (Al-10 wt.\% Si) coating on an IN738 superalloy was investigated at $1050{ }^{\circ} \mathrm{C}$ in air and in air plus water vapour. The resulting morphology of in situ diffusion barrier layer (DBL) within the aluminide coating is affected by oxidizing atmospheres; DBL can effectively retard the interdiffusion of aluminium within the coating. The location of the in situ DBL is governed by the partial pressure of oxygen at different depths from the oxide scales in both atmospheres. Meanwhile, the diffusion fluxes of different elements led to DBLs with different morphologies in the aluminide coating on the Ni-based alloy.
\end{abstract}

Keywords: metal coatings; superalloys; scanning electron microscopy (SEM); X-ray diffraction (XRD); selective oxidation

\section{Introduction}

Aluminide coatings are used on alloys to protect them from high-temperature corrosion in air with water vapour atmosphere because the aluminide coating can be seen as a reservoir of $\mathrm{Al}$ for forming and maintaining a protective $\mathrm{Al}_{2} \mathrm{O}_{3}$ scale on the substrate surface [1-5]. Meanwhile, the oxidation resistance of the aluminide coating has been further improved by the addition of some reactive elements, such as $\mathrm{Pt}, \mathrm{Hf}, \mathrm{Co}$ and $\mathrm{Si}$ [6-10]. Among them, a silicon-modified aluminide coating $(20 \mathrm{wt} . \% \mathrm{Si})$ shows a remarkable cyclic oxidation resistance at $1100{ }^{\circ} \mathrm{C}$ [11]. However, element interdiffusion between the aluminide coating and the substrate occurs during long-term oxidation at high temperature. Interdiffusion can continuously consume the $\mathrm{Al}$ and change the concentration of other elements within the aluminide coating, which seriously affects the oxidation resistance of the coating at high-temperature [12]. Clearly, interdiffusion also affects the oxidation resistance of the coating $[13,14]$.

To hinder the inward diffusion of $\mathrm{Al}$ to the substrate, a diffusion barrier layer (DBL) between the aluminide coating and superalloy can effectively prevent the interdiffusion of the elements. Electron beam physical vapour deposition (EB-PVD) [15,16] and cathodic electrodeposition [17] have been used to form DBLs on the alloys. Yao et al. [18] deposited a NiCrO interlayer $(1.8 \mu \mathrm{m})$ as the DBL on René N5 superalloy samples while using arc ion plating, and the NiCrO DBL effectively retarded the coating degradation during cyclic oxidation tests. A Re-based DBL deposition on a Ni-based superalloy via electroplating [19] inhibited interdiffusion of the elements between the aluminide coating and the substrate. However, the methods that are mentioned above require an additional deposition step, which increases the costs and possibility of spallation. To simplify the preparation of the DBL, a self-forming DBL has been demonstrated at the aluminide coating/substrate interface. The reason for forming the DBL is element interdiffusion between coating and substrate [20-22]. Ma et al. [23] reported the relationship between the 
growth and temperature of the DBL (intermetallic layer) that was formed in $\mathrm{Pd} / \mathrm{Cu}$ and $\mathrm{Pd} / \mathrm{Ag}$ porous stainless steel, the DBL formed by the oxidation of the substrate at $430{ }^{\circ} \mathrm{C}$, and the DBL was effective in reducing the intermetallic diffusion at $500^{\circ} \mathrm{C}$. Müller et al. [24] discussed the effects of reactive element oxides and the property of diffusion on a self-forming DBL on nickel-based superalloys, and the DBL was destroyed due to the reaction of $\mathrm{Y}$ and $\mathrm{Hf}$ from MCrAlY $(\mathrm{M}=\mathrm{Ni}, \mathrm{Co})$. The above studies indicated that the relationships between the growth, temperatures and reactive element oxides of the DBL, as well as its oxidation resistance, are complex and not yet fully understood at high temperature. Therefore, many factors affect the growth and morphology of the DBL. The relationship between the growth of the DBL and diffusion of elements in different atmospheres requires further study.

The purpose of this research was to understand the influence between the in situ DBL and the diffusion of elements during exposure to air and air plus water vapour environment. Moreover, the relationship between the external environment and the growth of DBL has been examined.

\section{Experimental}

A commercial IN738 superalloy was used as the substrate materials in this study. The IN738 superalloy was purchased from CISRI-GAONA, Beijing, China. The composition of the IN738 superalloy is shown in Table 1 . The superalloy was cut into disc-shaped specimens $(\varnothing 17 \mathrm{~mm} \times 3 \mathrm{~mm})$ using a wire electrical discharge machine. The hot-dipping procedure for preparing the aluminide coating was described in detail in our previous study [25]. The post-annealing processes were operated at $850{ }^{\circ} \mathrm{C}$ in argon for $24 \mathrm{~h}$ to homogenize the microstructure of the coatings. Cyclic oxidation tests were performed in a tube furnace that was equipped with a steam generator. During testing, the content of water vapour in the furnace was $25 \%$ [26].

Table 1. Chemical composition of the IN738 superalloy (wt.\%).

\begin{tabular}{c|cccccccccccc}
\hline Element & $\mathrm{Co}$ & $\mathrm{Cr}$ & $\mathrm{Ni}$ & $\mathrm{W}$ & $\mathrm{Mo}$ & $\mathrm{Al}$ & $\mathrm{Ti}$ & $\mathrm{Nb}$ & $\mathrm{Ta}$ & $\mathrm{Fe}$ & $\mathrm{C}$ & $\mathrm{B}$ \\
\hline IN738 & 8.5 & 16.1 & 61.565 & 2.4 & 1.5 & 3.7 & 3.5 & 1.1 & 1.5 & 0.03 & 0.1 & 0.005 \\
\hline
\end{tabular}

In each oxidation cycle, the specimens were heated in a $1050{ }^{\circ} \mathrm{C}$ furnace with air plus water vapour for $15 \mathrm{~h}$ and were then removed and cooled in the laboratory (approximately $25^{\circ} \mathrm{C}$ ) for $1 \mathrm{~h}$. For comparison, cyclic oxidation testing was also conducted in air without the addition of water vapour. Oxidation weight gains after different exposure durations $(15,30,45,60,75,90,105,120,135$, and $150 \mathrm{~h}$ ) in air and air plus water vapour were measured after cooling at room temperature while using an electronic balance ( $0.1 \mathrm{mg}$ accuracy). The process included three specimens per group.

The microstructures and elemental chemical composition of samples were determined while using field-emission scanning electron microscopy (SEM, FEI-Quanta 600, FEI, Hillsboro, OR, USA) in the backscattered electron (BSE) mode equipped with an energy-dispersive X-ray spectrometer (EDX, Oxford INCAx-sight 6427, Oxford Instruments, Abingdon, UK). The cross-sectional morphologies were characterized by electron probe microanalysis (EPMA, JEOL JXA-8230, JEOL Ltd., Tokyo, Japan). Phases in the aluminide coating surface were identified by X-ray diffraction (XRD) while using a D8 Focus diffractometer (Bruker, Billerica, MA, USA) with $\mathrm{Cu} \mathrm{K} \alpha 1$ radiation $(\lambda=0.15405 \mathrm{~nm})$ in the range of $2 \theta=20^{\circ}-90^{\circ}$ with a step size of $0.04^{\circ}$.

\section{Results and Discussion}

\subsection{Oxidation Kinetics and Surface Phases}

Figure 1 shows the cyclic oxidation kinetics curves of the aluminide coating. The curves demonstrate that the weight gains of the aluminide coating increased with time in air and air plus water vapour during the initial $45 \mathrm{~h}$. However, the weight gain decreased rapidly after $45 \mathrm{~h}$ due to the spallation of oxide scales within air plus water vapour. Spallation is caused by the internal stress within the oxide scales, and the stress is generated at the interface during growth of the oxide 
scales [27]. This result indicates serious spallation and the growth of the oxide scale in air plus water vapour. The kinetics curves approximately obeyed the parabolic law in air. A relatively stable oxide formed on the surface of the aluminide coating in air. But, the coating oxidized in air also exhibited spallation at $75 \mathrm{~h}$ and $135 \mathrm{~h}$, leading to the obvious fluctuation in the oxidation kinetics curve.

The XRD patterns of the aluminide coating oxidized at $1050^{\circ} \mathrm{C}$ are displayed in Figure 2. The X-ray patterns exhibit clear diffraction peaks, indicating the oxidation products for the samples in air and air plus water vapour. The external oxide scales were principally composed of $\mathrm{Si}_{3} \mathrm{Ti}_{5}$ in air, and other phases, such as $\mathrm{SiO}_{2}$ and $\mathrm{SiCr}_{3}$, are weakly detected. Moreover, the main phase of the external oxide scale is $\mathrm{Al}_{2} \mathrm{O}_{3}$ whether the coatings are oxidized in air or in air plus water vapour. Elements concentration gradient between the aluminide coating and substrate drive Ti migrate from substrate into aluminide coating during cyclic oxidation, so $\mathrm{Si}$ reacts with $\mathrm{Ti}_{\text {to }} \mathrm{Si}_{3} \mathrm{Ti}_{5}$. $\mathrm{Si}_{3} \mathrm{Ti}_{5}$ phase can easily react with water. So, water vapour leads to the formation of $\mathrm{SiO}_{2}$ and the destruction of the $\mathrm{Si}_{3} \mathrm{Ti}_{5}$ phase. Figure 3 shows the surface oxide morphologies formed on aluminide oxidized after $150 \mathrm{~h}$. Figure $3 \mathrm{a}$ indicates that the voids that were formed on partially localized oxide scales and spallation can be observed in air plus water vapour. The alloy surface is mostly covered with dense and unbroken $\mathrm{Al}_{2} \mathrm{O}_{3}$ scale, as shown in Figure $3 \mathrm{~b}$.

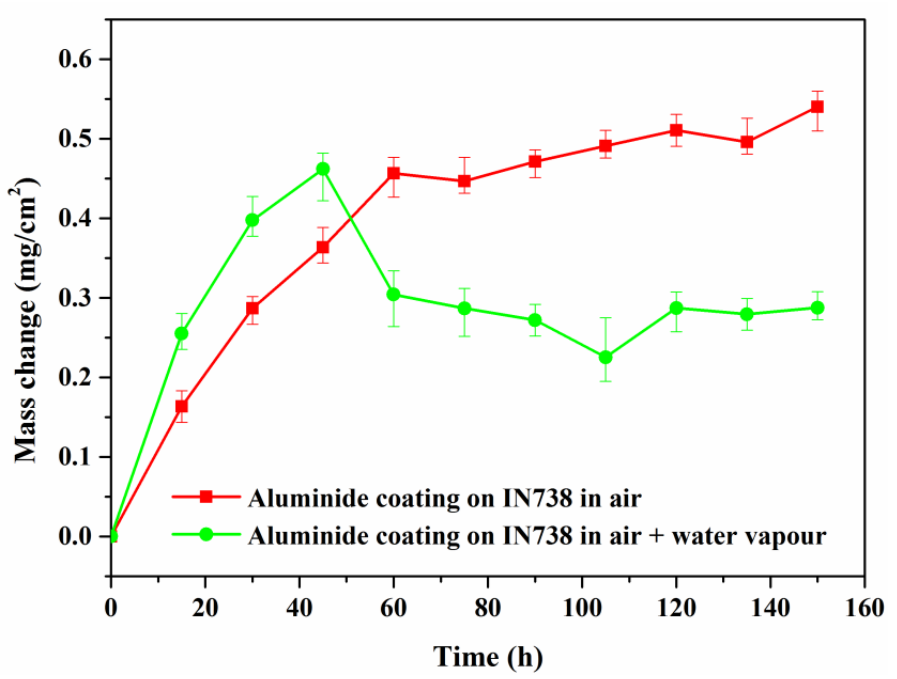

Figure 1. Cyclic oxidation kinetics of aluminide coating on an IN738 superalloy in air and air plus water vapour after being oxidized at $1050^{\circ} \mathrm{C}$ for $150 \mathrm{~h}$.

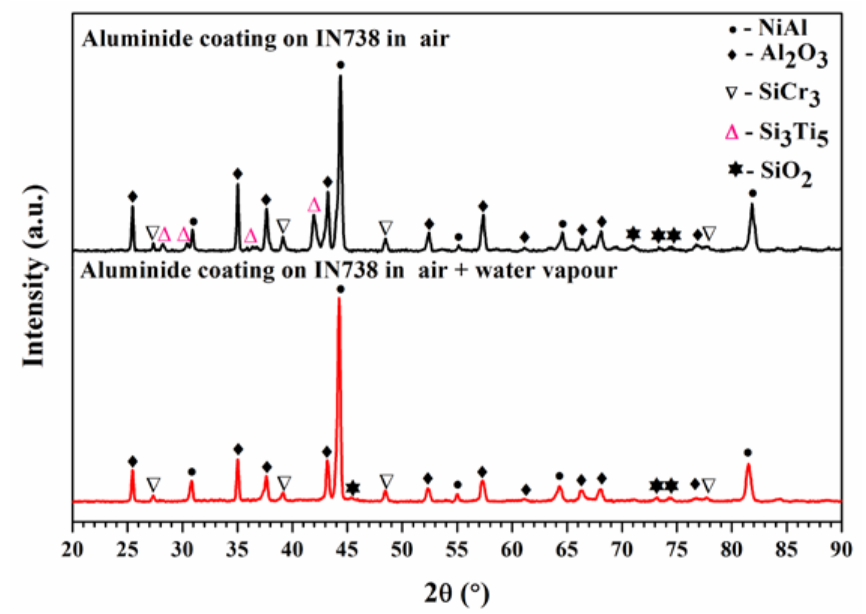

Figure 2. Surface X-ray diffraction (XRD) patterns for the aluminide coating on IN738 superalloy after $150 \mathrm{~h}$ of cyclic oxidation. 

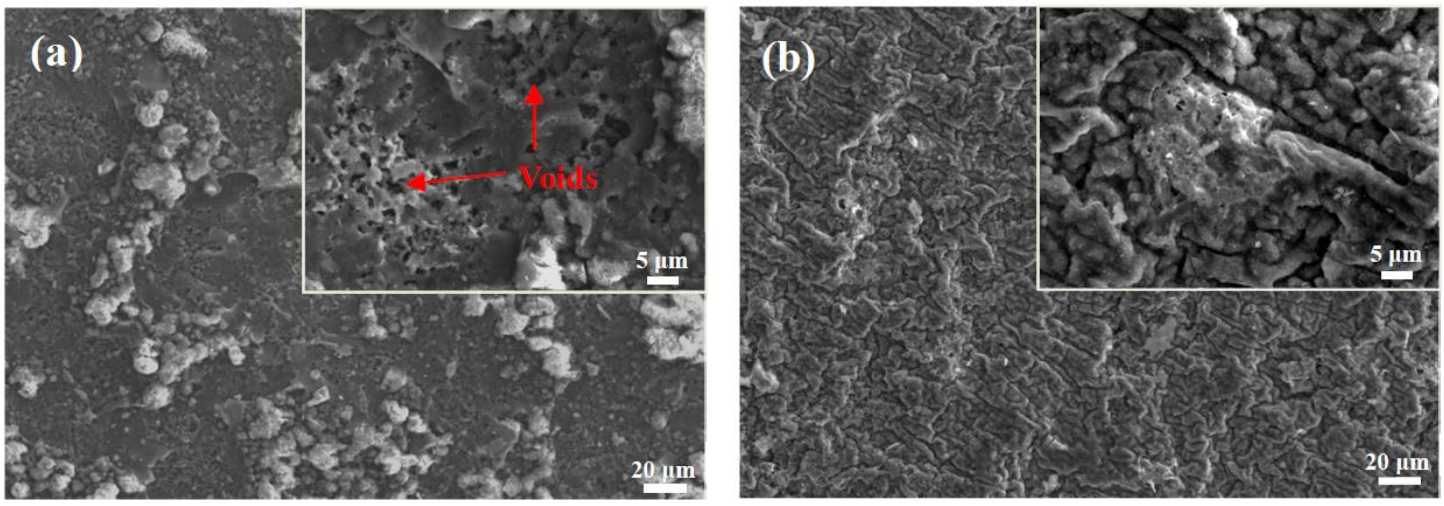

Figure 3. Surface morphologies of the aluminide coating on an IN738 superalloy in air and air plus water vapour after being oxidized at $1050{ }^{\circ} \mathrm{C}$ for $150 \mathrm{~h}$ : (a) in air + water vapour, and (b) in air.

\subsection{Cross-Sectional Structure and Chemical Composition}

The cross-sectional SEM microstructure, along with the element depth profiles of the specimen after $24 \mathrm{~h}$ of heat treatment in argon at $850{ }^{\circ} \mathrm{C}$, is shown in Figure 4. The cross-section SEM result shows no evidence of an interdiffusion zone. The element depth profiles show that the $\mathrm{Cr}$ content was approximately 40 at. $\%$ in the aluminide coating/substrate interface, whereas the $\mathrm{Al}$ content immediately decreased from $\sim 59$ at. $\%$ to $\sim 5$ at. $\%$ at the interface. Interdiffusion of $\mathrm{Cr}$ and $\mathrm{Al}$ between the aluminide coating and the substrate occurs simultaneously [28].

(a)

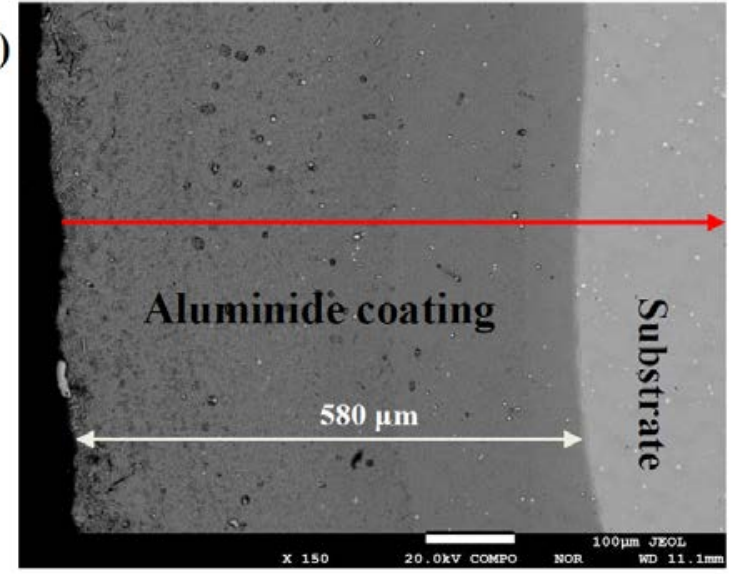

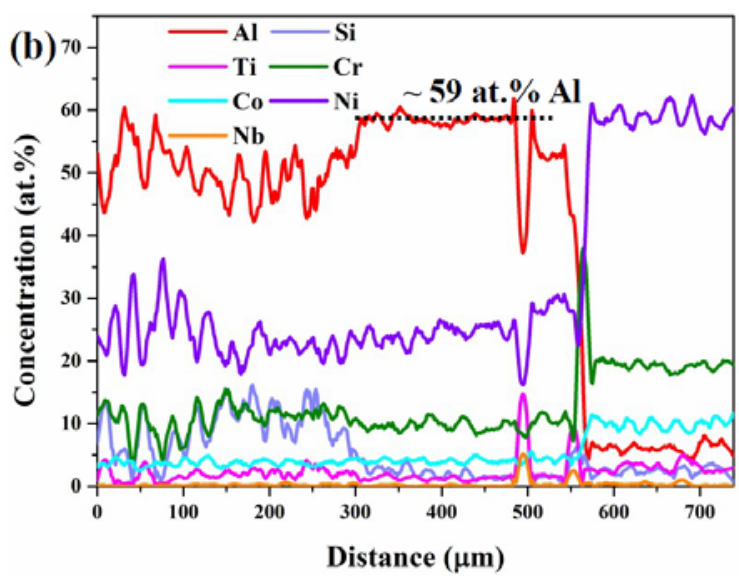

Figure 4. (a) Cross-sectional micrograph of the aluminide coating after been heat treated at $850{ }^{\circ} \mathrm{C}$ in argon for $24 \mathrm{~h}$, and (b) corresponding energy-dispersive X-ray spectrometer (EDX) line profiles of the elemental distributions across the aluminide layer on an IN738 superalloy.

Figure 5 shows SEM backscattered cross-sectional views of the samples oxidized in air plus water vapour and in air for $150 \mathrm{~h}$, respectively. Figure $5 \mathrm{a}$ indicates that a relatively thick scale $(\sim 10 \mu \mathrm{m})$ and a porous oxide layer were formed. Significant spallation in air plus water vapour led to a mass change after $45 \mathrm{~h}$ (Figure 1). However, in air, a thin continuous oxide layer formed with an average thickness of $5 \mu \mathrm{m}$, which appeared compact and uniform. Water vapour can increase the inward diffusion of $\mathrm{O}$ to increase the growth-rate of oxide [29]. Some internal oxides formed at the aluminide coating caused the rapid outward diffusion of $\mathrm{Al}$ in air plus water vapour. 

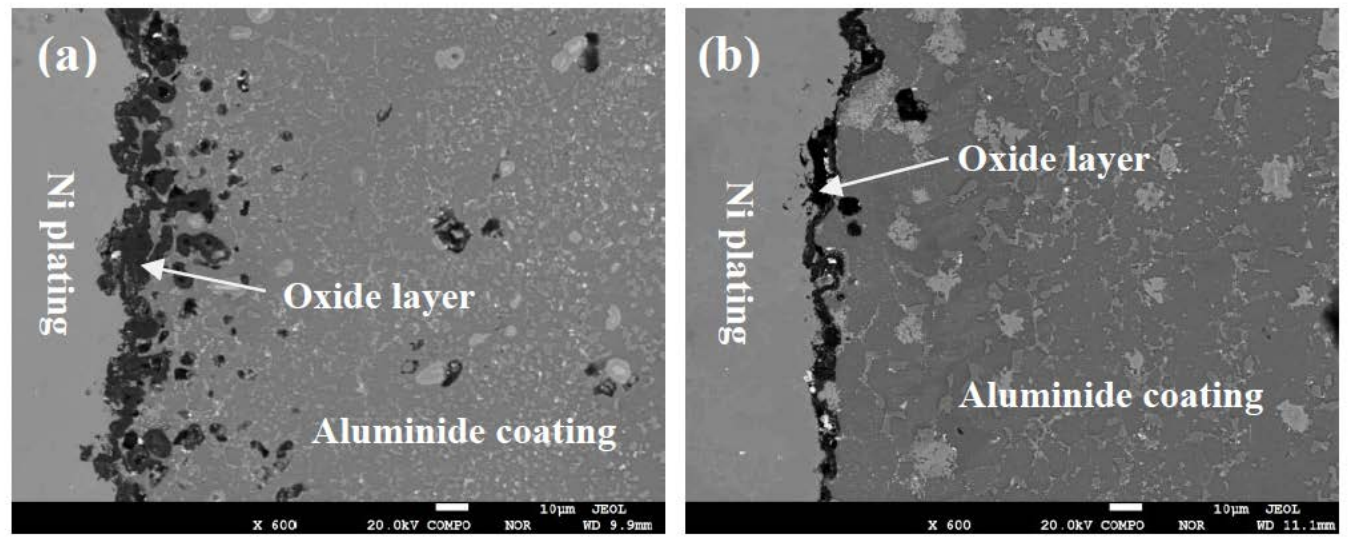

Figure 5. Cross-section SEM images of an aluminide coating on an IN738 superalloy in air and air plus water vapour after being oxidized at $1050{ }^{\circ} \mathrm{C}$ for $150 \mathrm{~h}$ : (a) in air + water vapour, and (b) in air.

The cross-sectional micrograph of aluminide coatings and the corresponding EDX line profiles of the elemental distributions across the coating layer on an IN738 superalloy are presented in Figure 6. Thickness of the Si-modified aluminide coating is approximately $218 \mu \mathrm{m}$ after $150 \mathrm{~h}$ of oxidation in air plus water vapour (Figure 6a). When compared with the thickness of the aluminide coating of the sample $(580 \mu \mathrm{m})$ at $850{ }^{\circ} \mathrm{C}$ in argon for $24 \mathrm{~h}$ (Figure $\left.4 \mathrm{a}\right)$, the thickness of the aluminide coating broadens after $150 \mathrm{~h}$ of oxidation in air.

The $\mathrm{Al}$ content was less than $\sim 32$ at. $\%$ in the aluminide coating in air plus water vapour, but the $\mathrm{Al}$ content was more than 45 at.\% in the aluminide coating which oxidized in air (Figure 6e,f). Figure $6 \mathrm{f}$ shows that the $\mathrm{Al}$ concentration exhibits a stepwise that decreased from the aluminide coating to substrate. However, the concentration of $\mathrm{Al}$ in the substrates was same ( 7 at.\%) both in air and water vapour atmospheres. It is worth noting that the $\mathrm{O}$ content is higher at the aluminide coating/DBL interface in air plus water vapour ( 10 at.\%) than that in air ( $\sim$ at.\%), as shown in Figure $6 c$.
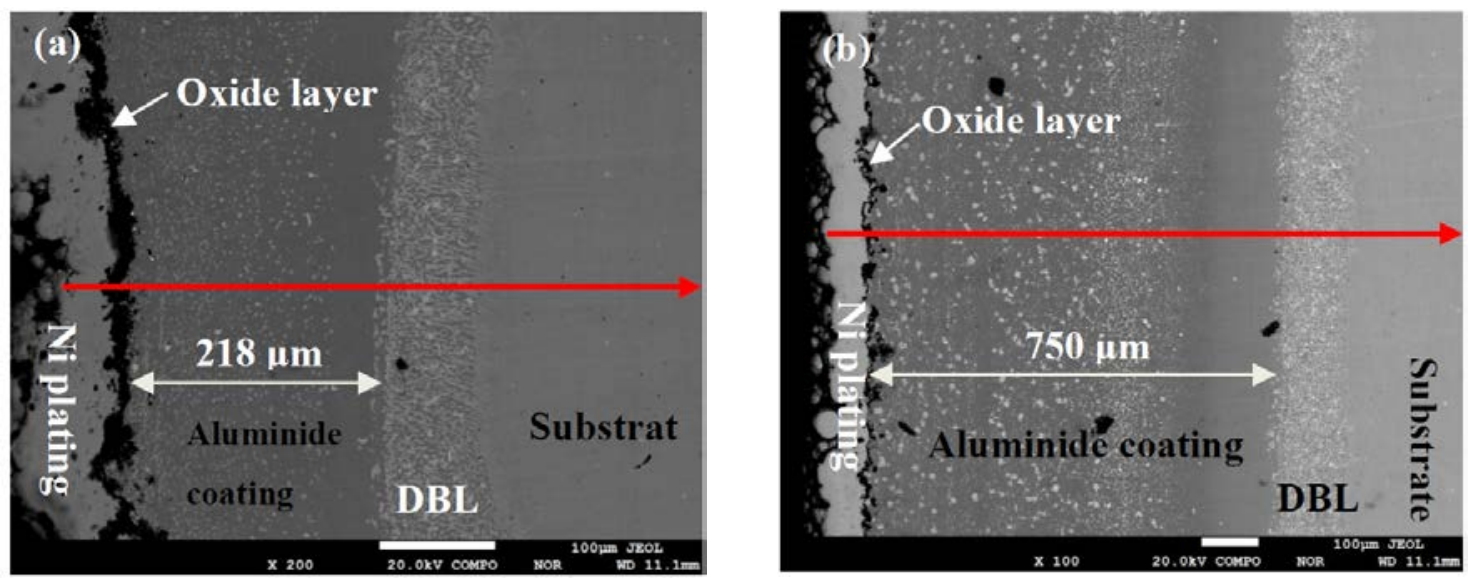

Figure 6. Cont. 

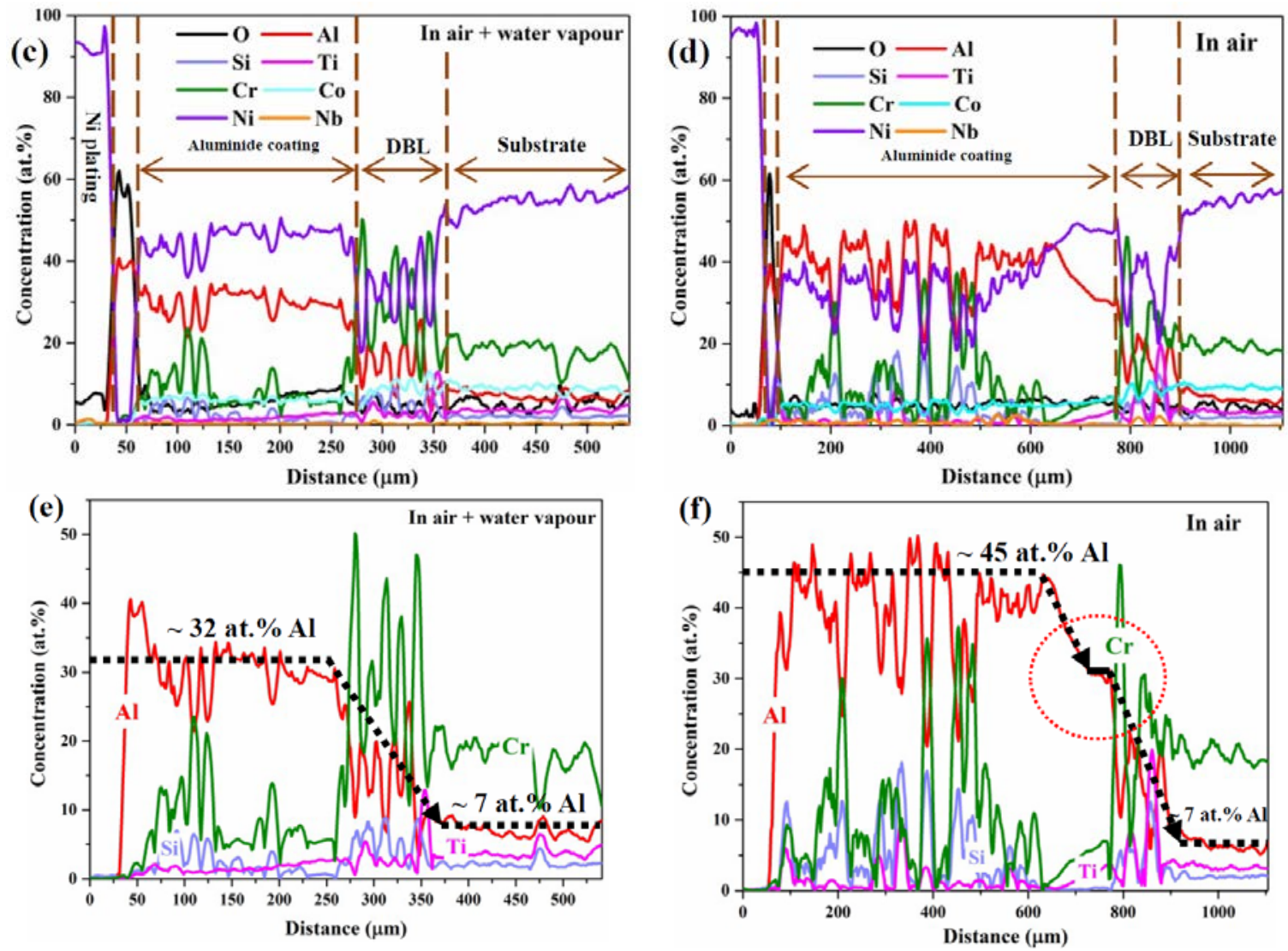

Figure 6. Cross-sectional micrograph of aluminide coatings oxidized at $1050{ }^{\circ} \mathrm{C}$ for $150 \mathrm{~h}$ : (a) in air plus water vapour and (b) in air; corresponding EDX line profiles of elemental distributions across the coating layer on an IN738 superalloy $(\mathbf{c}, \mathbf{e})$ in air plus water vapour; $(\mathbf{d}, \mathbf{f})$ in air.

\subsection{Differences in The Diffusion Barrier Layer}

The cross-section EPMA mappings of aluminide coating after oxidation in air and in air plus water vapour for $150 \mathrm{~h}$ are shown in Figure 7. Figure 7a illustrates that $\mathrm{O}$ tends to distribute in the topmost interface between the aluminide coating and $\mathrm{DBL}$, where it also contained $\mathrm{Nb}$ and a small volume of Ti. According to the mapping results (Figure $7 \mathrm{~b}$ ), a Cr-rich layer formed at the aluminide coating/DBL interface, which was formed due to the outward diffusion of Cr during the oxidation process. The DBL can preserve the Al element diffusion between the aluminide coating and substrate; therefore, the oxidation resistance of the aluminide coating has not been affected via interdiffusion. When compared with the distribution of Si element in air plus water vapour (Figure 7a), there is no obvious difference in the distribution of Si element in air.

The oxygen flux through the internal oxidation zone is given by Fick's first law, as Equation (1):

$$
\begin{gathered}
J_{\mathrm{O}}=D_{\mathrm{O}} \frac{N_{\mathrm{O}}^{(\mathrm{s})}}{X V_{m}}\left(\mathrm{~mol} \cdot \mathrm{cm}^{-2} \mathrm{~s}^{-1}\right) \\
m=\frac{N_{B}^{(\mathrm{O})} v X}{V_{m}}\left(\mathrm{~mol} \cdot \mathrm{cm}^{-2}\right)
\end{gathered}
$$

where $N_{\mathrm{O}}{ }^{(\mathrm{s})}$ is the oxygen solution in alloy, $V_{m}$ is the molar volume of the solvent metal or alloy $\left(\mathrm{cm}^{3} \cdot \mathrm{mol}^{-1}\right), v$ is the drift velocity of oxygen, $X$ is the diffusion depth, and $D_{\mathrm{O}}$ is the diffusivity of oxygen in alloy $\left(\mathrm{cm}^{2} \cdot \mathrm{s}^{-2}\right)$. If counter-diffusion of another element is assumed to be negligible, the amount of oxygen accumulated in the internal oxidation zone per unit area of reaction front is given by Equation (2), where $N_{\mathrm{O}}{ }^{(\mathrm{O})}$ is the initial solute concentration. According to Equation (2), $\mathrm{O}$ is enriched 
at the interface between the aluminide coating and DBL when the amount of oxygen is much less than the critical value of the oxidation reaction.
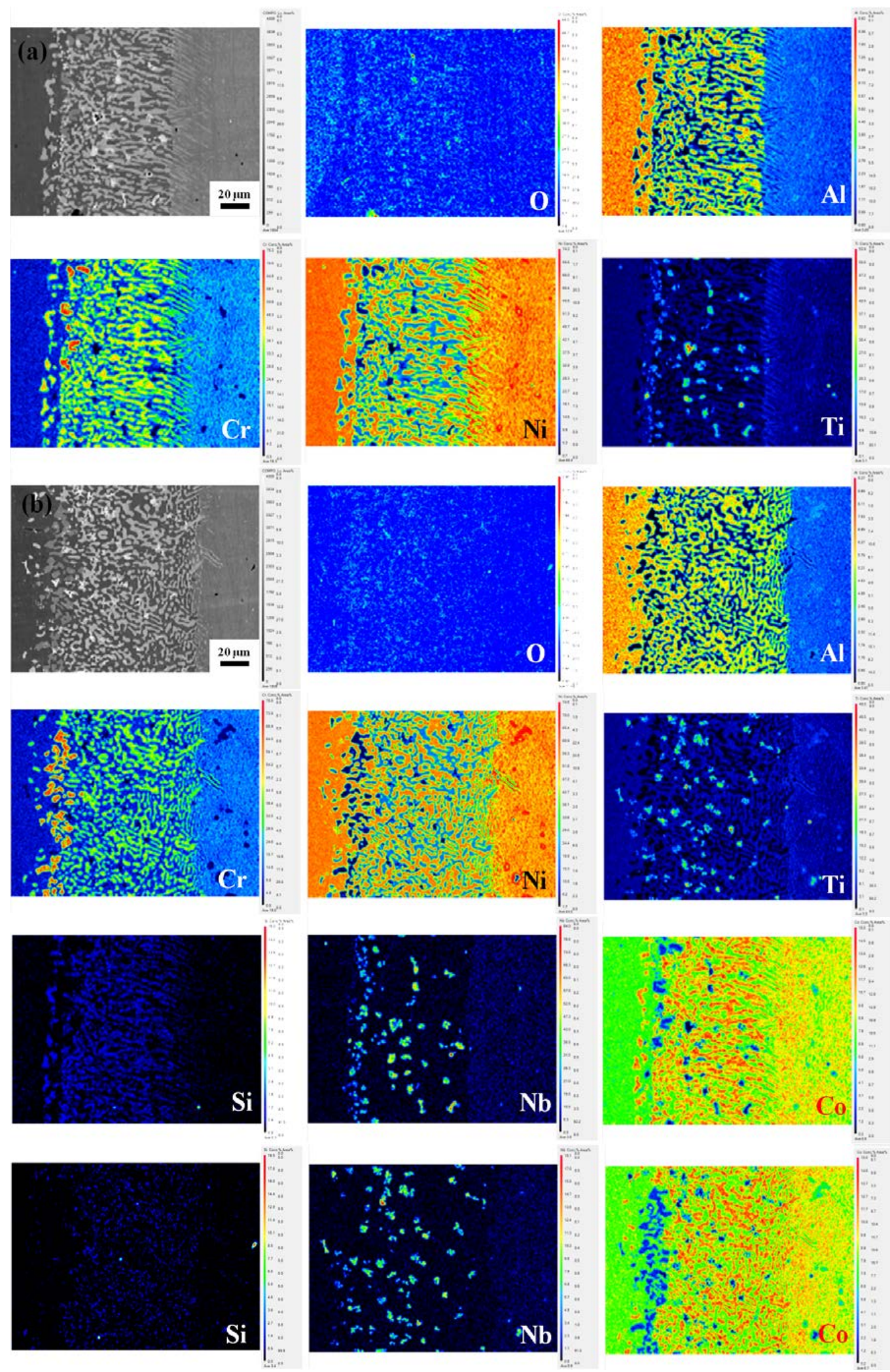

Figure 7. Electron probe microanalysis (EPMA0 elemental mappings of aluminide coating on IN738 after being oxidized at $1050{ }^{\circ} \mathrm{C}$ for $150 \mathrm{~h}$ : (a) in air plus water vapour and (b) in air. 
Figure 8a shows the typical cross-sectional microstructure of the interdiffusion zone in air plus water vapour. When compared with the samples oxidized in air (Figure 8b), the in situ DBL (Si/Cr-rich phases) in air plus water vapour has a different morphology. The high partial pressure of $\mathrm{O}\left(P_{\mathrm{O}}\right)$ promoted the lateral growth of the DBL in air plus water vapour, while low $P_{\mathrm{O}}$ inhibited its lateral growth in air The $\mathrm{Al}$ in the aluminide coating was mainly depleted by the outward diffusion of $\mathrm{Al}$, due to form a $\mathrm{Al}_{2} \mathrm{O}_{3}$ scale in air plus water vapour, and the concentration of $\mathrm{O}\left(\mathrm{C}_{\mathrm{O} \text { (water) }}\right)$ increased in air plus water vapour due to severe spallation on the oxide scale [26]. High $C_{\mathrm{O} \text { (water) }}$ decreases the concentration of $\mathrm{Al}\left(C_{\mathrm{Al}}\right)$ in the aluminide coating too much (32 at.\%). Meanwhile, the low $C_{\mathrm{Al}}$ within the aluminide coating also corresponded to a lower diffusion flux of $\mathrm{Al}\left(\mathrm{J}_{\mathrm{Al}}\right)$ near the $\mathrm{DBL}$, as shown in Figure 8c. During the oxidation process, the aluminide coating was directly oxidized, but $\mathrm{Al}$ consumption was accelerated in air plus water vapour because the $P_{\mathrm{O}}$ in the oxide/aluminide coating interface was higher than that in air. The outward diffusion of $\mathrm{Al}$ is dominant in the aluminide coating, and the outward diffusion of $\mathrm{Cr}$ increased in the substrate due to the high $P_{\mathrm{O}}$ in the aluminide coating in air plus water vapour. Accordingly, $J_{\mathrm{Al}}$ was lower than the diffusion flux of $\mathrm{Cr}\left(J_{\mathrm{Cr}}\right)$ on both sides of DBL. Xiang et al. [30] suggested that $\mathrm{Cr}$ can substantially decrease the activity of Al. High $J_{\mathrm{Cr}}$ can inhibit the inward diffusion of Al. Therefore, as a driving force for the evolution of DBL, high $J_{\mathrm{Cr}}$ promotes the outward movement of the diffusion layer, which decreases the thickness of the aluminide coating [31]. The movement of the interdiffusion zone on an IN738 superalloy during oxidation in air plus water vapour is shown in Figure 9a.
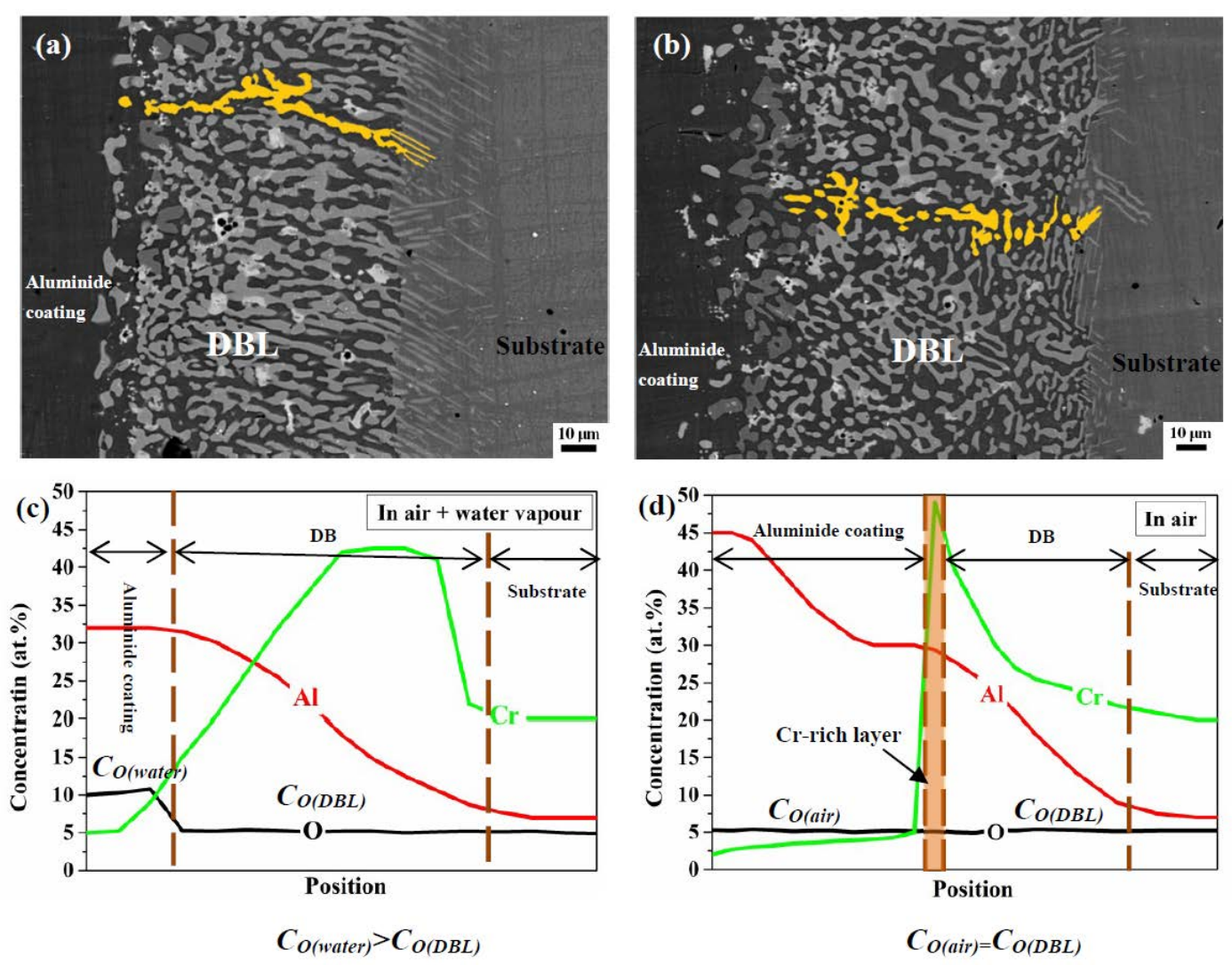

Figure 8. Micrograph of interdiffusion zone oxidized at $1050{ }^{\circ} \mathrm{C}$ for $150 \mathrm{~h}$ : (a) in air plus water vapour and (b) in air; schematic of the elemental content of the interdiffusion zone on an IN738 superalloy after being oxidized for $150 \mathrm{~h}(\mathbf{c})$ in air plus water vapour and (d) in air at $1050{ }^{\circ} \mathrm{C}$. 
(a)

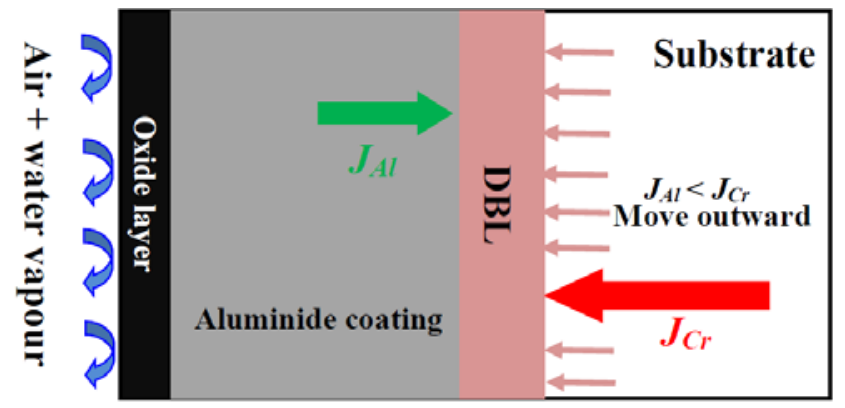

(b)

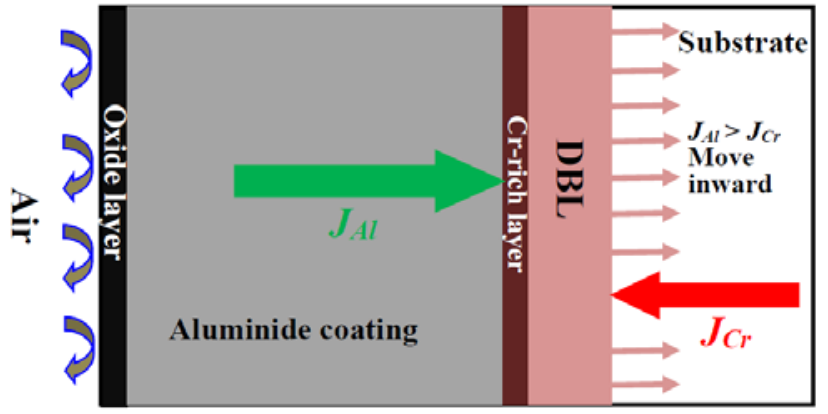

Figure 9. Schematic of the movement of the interdiffusion zone on an IN738 superalloy after being oxidized for $150 \mathrm{~h}$ : (a) in air plus water vapour and (b) in air at $1050{ }^{\circ} \mathrm{C}$.

The Si/Cr-rich layer as a DBL within the aluminide coating has a low diffusion flux of $\mathrm{O}\left(J_{O}\right)$, thus just allowing a small amount of $\mathrm{O}$ to pass through this layer. Oxygen can diffuse through the coating to the substrate, where it can be detected by EDS [32,33]. Similar to a dam, the DBL blocks interdiffusion between the aluminide coating and substrate. Therefore, low $P_{\mathrm{O}}$ in air contributed to the lower $C_{\mathrm{O}(\mathrm{air})}$ than that in air plus water vapour, as shown in Figure 8d. Moreover, when $J_{\mathrm{Al}}$ was far greater than $J_{\mathrm{Al} \text { (water) }} \mathrm{Al}$ enrichment at the aluminide coating/DBL interface was promoted. $\mathrm{Al}$ in the aluminide layer mainly depleted by the inward diffusion of $\mathrm{Al}$ to the substrate in air, because dense $\mathrm{Al}_{2} \mathrm{O}_{3}$ was formed at the surface, leading to a small amount of $\mathrm{O}$ inward diffusion to the aluminide coating in air. High $J_{\mathrm{Al}}$ promotes the inward movement of the DBL, as shown in Figure 9b. Yao et al. [18] observed $\mathrm{Cr}$ segregation occurred in the interdiffusion zone for the NiAl coating after 2001 -h cycles at $1100{ }^{\circ} \mathrm{C}$ in air. High $J_{\mathrm{Al}}$ hinders the $\mathrm{Cr}$ outward diffusion from the substrate to the aluminide coating, which leads to the enrichment of $\mathrm{Cr}$ in the DBL. The oxidizing environment affects the movement of the DBL, which in turn, changes the concentration of elements in the aluminide coating. Therefore, the evolution of the DBL and oxidation behaviour can affect each other.

We believe that a systematic study of the DBL within the aluminide coating on an IN738 superalloy could provide valuable information on the oxidation resistance of aluminidecoating-substrate assemblies.

\section{Conclusions}

In summary, a silicon-doped aluminide coating is prepared on an IN738 superalloy. The main conclusions are summarized below:

- The Si/Cr-rich DBL formed at the aluminide coating/substrate interface after cyclic oxidation can prevent the $\mathrm{Al}$ inward diffusion, both in air and in air plus water vapour.

- A Cr-rich layer formed at the aluminide coating/DBL interface in air, and the Cr-rich layer can further prevent the inward diffusion of Al. Water vapour inhibits the formation of the $\mathrm{Cr}$-rich layer.

- A high Cr content can cause the DBL to move outward in air plus water vapour; however, a high $\mathrm{Al}$ content within the aluminide coating can drive the DBL inward in air. 
Author Contributions: Conceptualization, C.L. and P.S.; Methodology, J.L.; Software, X.H.; Validation, K.C., X.Y. and P.S.; Formal Analysis, X.H., K.C. and X.Y.; Investigation, C.L.; Resources, P.S.; Data Curation, J.L.; Writing-Original Draft Preparation, C.L.; Writing-Review \& Editing, C.L. and P.S.; Visualization, K.C.; Supervision, P.S. and J.L.; Project Administration, P.S.

Funding: This research was funded by the National Natural Science Foundation of China (No. 51401097), Yunnan Province Science and Technology Major Project (No. 2018ZE009) and Yunnan Province Key Research and Development Program (No. 2018BA067).

Acknowledgments: Authors acknowledged the Facility for Analysis, Characterisation and Testing, Kunming University of Science and Technology (KUST), for use of their electron microscopy facilities.

Conflicts of Interest: The authors declare no conflict of interest.

\section{References}

1. Vaezi, M.; Soleymani, M. Creep life prediction of inconel 738 gas turbine blade. J. Appl. Sci. 2009, 9, $1950-1955$. [CrossRef]

2. Onal, K.; Maris-Sida, M.C.; Meier, G.H.; Pettit, F.S. Water vapor effects on the cyclic oxidation resistance of alumina forming alloys. Mater. High Temp. 2003, 20, 327-337. [CrossRef]

3. Su, C.W.; Lee, J.W.; Wang, C.S.; Chao, C.G.; Liu, T.F. The effect of hot-dipped aluminum coatings on Fe-8Al-30Mn-0.8C alloy. Surf. Coat. Technol. 2008, 202, 1847-1852. [CrossRef]

4. El-Awadi, G.A.; Abdel-Samad, S.; Elshazly, E.S. Hot corrosion behavior of Ni based inconel 617 and inconel 738 superalloys. Appl. Surf. Sci. 2016, 378, 224-230. [CrossRef]

5. Koo, C.H.; Bai, C.Y.; Luo, Y.J. The structure and high temperature corrosion behavior of pack aluminized coatings on superalloy IN-738LC. Mater. Chem. Phys. 2004, 86, 258-268. [CrossRef]

6. Das, D.K.; Singh, V.; Joshi, S.V. Effect of Al content on microstructure and cyclic oxidation performance of Pt-aluminide coatings. Oxid. Met. 2002, 57, 245-266. [CrossRef]

7. Moretto, P.; Bressers, J.; Arrell, D.J. Evolution of a PtAl 2 coating on the nickel-base alloy CMSX-6 subjected to thermo-mechanical fatigue. Mater. Sci. Eng. A 1999, 272, 310-320. [CrossRef]

8. Xiang, Z.D.; Datta, P.K. Formation of Hf- and W-modified aluminide coatings on nickel-base superalloys by the pack cementation process. Mater. Sci. Eng. A 2003, 363, 185-192. [CrossRef]

9. Yang, Y.F.; Jiang, C.Y.; Yao, H.R.; Bao, Z.B.; Zhu, S.L.; Wang, F.H. Preparation and enhanced oxidation performance of a Hf-doped single-phase Pt-modified aluminide coating. Corros. Sci. 2016, 113, 17-25. [CrossRef]

10. He, H.; Liu, Z.; Wang, W.; Zhou, C. Microstructure and hot corrosion behavior of Co-Si modified aluminide coating on nickel based superalloys. Corros. Sci. 2015, 100, 466-473. [CrossRef]

11. Shirvani, K.; Saremi, M.; Nishikata, A.; Tsuru, T. The role of silicon on microstructure and high temperature performance of aluminide coating on superalloy In-738LC. Mater. Trans. 2002, 43, 2622-2628. [CrossRef]

12. Pint, B.A. The role of chemical composition on the oxidation performance of aluminide coatings. Surf. Coat. Technol. 2004, 188, 71-78. [CrossRef]

13. Rahmani, K.; Nategh, S. Influence of aluminide diffusion coating on the tensile properties of the Ni-base superalloy René 80. Surf. Coat. Technol. 2008, 202, 1385-1391. [CrossRef]

14. Pyczak, F.; Devrient, B.; Neuner, F.C.; Mughrabi, H. The influence of different alloying elements on the development of the $\Upsilon / \Upsilon^{\prime}$ microstructure of nickel-base superalloys during high-temperature annealing and deformation. Acta Mater. 2005, 53, 3879-3891. [CrossRef]

15. Xu, Z.; He, L.; Mua, R.; Zhong, X.; Cao, X. Formation of diffusion barrier on the Ni-based superalloy by low-pressure pre-oxidation. Vacuum 2008, 82, 1251-1258. [CrossRef]

16. Peng, H.; Guo, H.; Yao, R.; He, J.; Gong, S. Improved oxidation resistance and diffusion barrier behaviors of gradient oxide dispersed NiCoCrAlY coatings on superalloy. Vacuum 2010, 85, 627-633. [CrossRef]

17. Bouchaud, B.; Rannou, B.; Pedraza, F. Slurry aluminizing mechanisms of Ni-based superalloys incorporating an electrosynthesized ceria diffusion barrier. Mater. Chem. Phys. 2013, 143, 416-424. [CrossRef]

18. Yao, H.; Bao, Z.; Shen, M.; Zhua, S.; Wang, F. A magnetron sputtered microcrystalline $\beta$-NiAl coating for SC superalloys. Part II. Effects of a NiCrO diffusion barrier on oxidation behavior at $1100{ }^{\circ} \mathrm{C}$. Appl. Surf. Sci. 2017, 407, 485-494. [CrossRef]

19. Ghasemi, R.; Valefi, Z. Electrodeposition of rhenium-base layer as a diffusion barrier between the NiCoCrAlY coating and a Ni-based superalloy. J. Alloy. Compd. 2018, 732, 470-485. [CrossRef] 
20. Wang, Y.; Tang, B.; Li, F. The properties of self-formed diffusion barrier layer in $\mathrm{Cu}(\mathrm{Cr})$ alloy. Vacuum 2016, 126, 51-54. [CrossRef]

21. Song, Z.X.; Wang, J.A.; Li, Y.H.; Ma, F.; Xu, K.W.; Guo, S.W. The self-formation graded diffusion barrier of $\mathrm{Zr} / \mathrm{ZrN}$. Microelectron. Eng. 2010, 87, 391-393. [CrossRef]

22. Xu, Y.; Chirol, M.; Li, C.; Vardelle, A. Formation of $\mathrm{Al}_{2} \mathrm{O}_{3}$ diffusion barrier in cold-sprayed NiCoCrAlY $/ \mathrm{Ni}$ multi-layered coatings on 304SS substrate. Surf. Coat. Technol. 2016, 307, 603-609. [CrossRef]

23. Ma, Y.H.; Akis, B.C.; Ayturk, M.E.; Guazzone, F.; Engwall, E.E.; Mardilovich, I.P. Characterization of intermetallic diffusion barrier and alloy formation for $\mathrm{Pd} / \mathrm{Cu}$ and $\mathrm{Pd} / \mathrm{Ag}$ porous stainless steel composite membranes. Ind. Eng. Chem. Res. 2004, 43, 2936-2945. [CrossRef]

24. Müller, J.; Schierling, M.; Zimmermann, E.; Neuschütz, D. Chemical vapor deposition of smooth $\alpha-\mathrm{Al}_{2} \mathrm{O}_{3}$ films on nickel base superalloys as diffusion barriers. Surf. Coat. Technol. 1999, 120, 16-21. [CrossRef]

25. Zang, J.; Song, P.; Feng, J.; Xiong, X.; Chen, R.; Liu, G.; Lu, J. Oxidation behaviour of the nickel-based superalloy DZ125 hot-dipped with Al coatings doped by Si. Corros. Sci. 2016, 112, 170-179. [CrossRef]

26. Li, C.; Song, P.; Khan, A.; Feng, J.; Chen, K.; Zang, J.; Xiong, X.; Lü, J.; Lu, J. Influence of water vapour on the $\mathrm{HfO}_{2}$ distribution within the oxide layer on CoNiCrAlHf alloys. J. Alloy. Compd. 2018, 739, 690-699. [CrossRef]

27. Michael Schütze, Mechanical properties of oxide scales. Oxid. Met. 1995, 44, 29-61. [CrossRef]

28. Doolabi, M.S.; Ghasemi, B.; Sadrnezhaad, S.K.; Feizabadi, A.; Habibollah Zadeh, A.; Salehi Doolabi, D.; AsadiZarch, M. Comparison of isothermal with cyclic oxidation behavior of "Cr-aluminide" coating on inconel 738LC at $900{ }^{\circ}$ C. Oxid. Met. 2017, 87, 57-74. [CrossRef]

29. Zhou, C.G.; Yu, J.S.; Gong, S.K.; Xu, H.B. Influence of water vapor on the isothermal oxidation behavior of low pressure plasma sprayed NiCrAlY coating at high temperature. Surf. Coat. Technol. 2002, 161, 86-91. [CrossRef]

30. Xiang, Z.D.; Burnell-Gray, J.S.; Datta, P.K. Aluminide coating formation on nickel-base superalloys by pack cementation process. J. Mater. Sci. 2001, 36, 5673-5682. [CrossRef]

31. Narita, T. Diffusion barrier coating system concept for high temperature applications. Can. Metall. Q. 2011, 50, 278-290. [CrossRef]

32. Cheng, Y.X.; Wang, W.; Zhu, S.L.; Xin, L.; Wang, F.H. Arc ion plated- $\mathrm{Cr}_{2} \mathrm{O}_{3}$ intermediate film as a diffusion barrier between NiCrAlY and $\Upsilon$-TiAl. Intermetallics 2018, 18, 736-739. [CrossRef]

33. Katsumata, Y.; Yoshioka, T.; Thosin, K.Z.; Nishimoto, T.; Izumi, T.; Hayashi, S.; Narita, T. Formation and oxidation behavior of a diffusion-barrier-coating system on a Ni-Mo base alloy at $1373 \mathrm{~K}$ in Air. Oxid. Met. 2007, 68, 331-342. [CrossRef]

(C) 2018 by the authors. Licensee MDPI, Basel, Switzerland. This article is an open access article distributed under the terms and conditions of the Creative Commons Attribution (CC BY) license (http://creativecommons.org/licenses/by/4.0/). 